\title{
Rural-urban income disparity and WTO impact on China's agricultural sector Policy considerations
}

\section{Xiaolu Wang and Ron Duncan}

Since the beginning of agricultural reform in the late 1970s and early 1980s, grain output in China has increased significantly. The long-standing problem of grain supply shortages has basically been solved. However, grain production and pricing are still not fully liberalised and large fluctuations in grain prices, together with short-term shortages and surpluses of grain, have occurred several times. These events have seriously affected farmers' incomes. Partly as a result, rural-urban income disparities have grown, particularly in the 1990s.

In 2001, China entered the World Trade Organization (WTO). Because of the commitment made to open the domestic market for agricultural products, grain imports are increasing rapidly. Domestic grain production and farmers' incomes are facing new challenges. This chapter examines recent developments in rural-urban income differentials, especially in light of WTO commitments, the appropriateness of related domestic policies such as grain pricing and urbanisation policies, and the effects of adjustments of these policies in response to the new challenges.

\section{Agriculture and rural-urban income disparity in China}

After half a century of rapid industrialisation, the dominant role of China's agricultural sector (including farming, forestry, animal husbandry and 
fisheries) in the economy has been replaced by the industry and service sectors. In spite of significant growth in agricultural production, the share of the agricultural sector in GDP declined from 51 per cent to only 15 per cent from 1952 to 2001. However, because of the large size and continued growth of the rural population, the employment structure of the agricultural and non-agricultural sectors changed far more slowly than the change in the output structure. Agricultural employment accounted for 84 per cent of total employment in 1952, and declined to 50 per cent in 2001. At the same time, agricultural employment increased from 173 million to 365 million. ${ }^{1}$

The share of the rural population changed even more slowly. The rural population still accounts for 62 per cent of China's total population, as compared to 85 per cent in 1953 (Table 4.1).

Farming remains the most important component of Chinese agriculture; although reduced, it still accounted for 55 per cent of the gross value of agricultural output in year 2001. Surveys show that, in year 2000, 51 per cent of rural household income came from the agricultural sector as a whole and 39 per cent from farming (Figure 4.1). Grain production has been the major farming activity, especially in less developed regions.

Movement of the agricultural population to non-agricultural sectors was hampered by the restrictive central policies during the pre-reform period from the 1950s to the late 1970s. Rural industrialisation and urbanisation has been speeded up since the market reforms. Such developments have provided close to 200 million additional non-agricultural jobs to farmers in rural and urban areas over the past 24 years. Still, the number of farmers has increased and there appears to be more surplus agricultural labour than ever before. Rural income grew slowly, and differences between rural and urban incomes became larger.

Table 4.2 shows changes in income per capita in rural and urban areas of China and its three major regions from 1980 to 2000. It shows that rural income per capita in rural areas was 47 per cent of urban income in 1980; this ratio had declined to 35 per cent by 2000 . Rural-urban income disparity increased in all three regions, but more seriously in the least-developed west region where the rural-urban income ratio fell from 45 to 30 per cent during the same period. In year 2000, the average annual rural income per capita in the west region was 1,713 yuan (or US\$207), only half of the average rural income in the east region. 
Table 4.1 The importance of the agricultural and rural sectors in China, 1952 and 2001

\begin{tabular}{lrr}
\hline & 1952 & 2001 \\
& & \\
Agricultural value-added & 34 & 1,461 \\
$\quad$ Billion yuan & 51 & 15 \\
per cent of GDP & & \\
Agricultural workers & 173 & 365 \\
$\quad$ Million persons & 84 & 50 \\
per cent of total employment & $505^{*}$ & 796 \\
Rural population & 85 & 62 \\
Million persons & & \\
per cent of total population & & \\
& & \\
\hline * 1953 data. & & \\
Source: Calculated from National Bureau of Statistics, 2002, 1999b. Statistical Yearbook \\
of China, China Statistics Press, Beijing. \\
\hline
\end{tabular}

Figure 4.1 The structure of rural household income, 2000

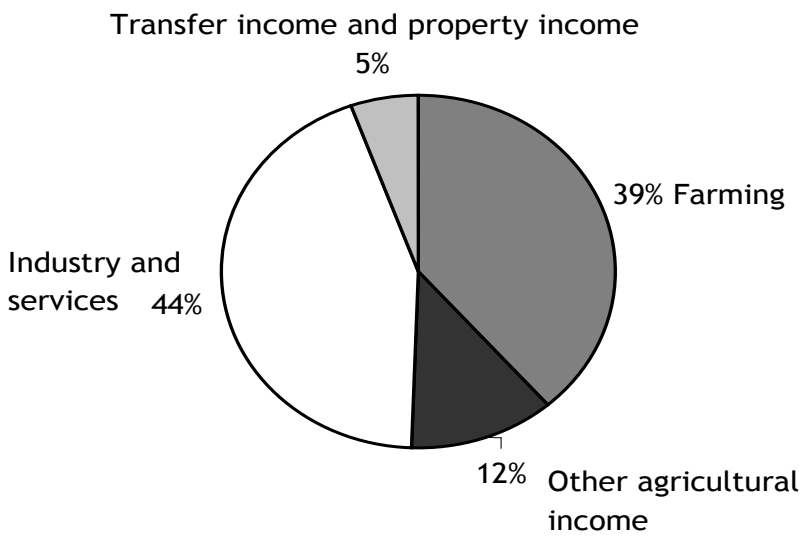

Source: National Bureau of Statistics, 2001. Statistical Yearbook of China, China Statistics Press, Beijing. 
Table 4.2 Rural-urban income disparity, 1980 and 2000 (yuan in current prices)

\begin{tabular}{lcccccc}
\hline & Urban & $\begin{array}{c}1980 \\
\text { Rural }\end{array}$ & $\begin{array}{c}\text { Rural/urban } \\
\text { (per cent) }\end{array}$ & Urban & $\begin{array}{c}2000 \\
\text { Rural }\end{array}$ & $\begin{array}{c}\text { Rural/urban } \\
\text { (per cent) }\end{array}$ \\
East & 452 & 246 & 54.4 & 7,940 & 3,429 & 43.2 \\
Central & 386 & 191 & 49.5 & 5,217 & 2,091 & 40.1 \\
West & 383 & 172 & 44.9 & 5,642 & 1,713 & 30.4 \\
China & 413 & 193 & 46.7 & 6,635 & 2,301 & 34.7 \\
\hline
\end{tabular}

Note: incomes are calculated by the authors as weighted averages from urban disposable income and rural pure income at the provincial level.

Source: National Bureau of Statistics, 2000a, 2001. Statistical Yearbook of China, China Statistics Press, Beijing.

\section{The impact of WTO accession on agriculture and rural incomes}

In 2001, China acceded to the WTO and committed to open its domestic food markets to imports to a much larger extent. There were several immediate changes in agricultural product trade policies following China's accession. The most important policies can be summarised as

- China accepted a tariff rate quota (TRQ) for major grain imports (wheat, corn and rice) at a token tariff rate of 1 per cent. The quota was 18.31 million tonnes for 2002, 20.2 million tonnes for 2003, and 22.16 million tonnes for 2004 (WTO, 2001). The quota is shared between the state and private trading enterprises, and all unused state quotas are to be transferred to private enterprises.

- The above-quota tariff rate for the major grains is 65 per cent. ${ }^{2}$ There is no import quota for soybeans. The tariff rate for soybeans is 3 per cent

- The average tariff rate for all agricultural products is to be reduced from 22 to 17.5 per cent.

- All export subsidies are to be eliminated. 
- Other non-tariff restrictions on imports of agricultural products, such as licensing, are to be eliminated. This includes restrictions on imports of wheat from the northwest areas of North America which may have TCK disease (a fungal disease).

The import quota of 22 million tonnes is large compared with the historical level of imports. During the $1990 \mathrm{~s}$, the average annual imports of grain were 9.0 million tonnes, and there were net exports of 0.8 million tonnes annually. There was only one year, 1995, when grain imports exceeded 20 million tonnes, and this resulted in a serious surplus of grain on the domestic market. The 2004 import quota is equal to 5.5 per cent of the total output in year 2000-not a very large proportion-however, the size of the domestic grain market is far smaller than total output, because half of the grain output is consumed by farmers and does not enter the market. Calculations show that the 2004 TRQ accounts for 11.9 per cent of the domestic grain market. It is estimated that full utilisation of the TRQ in the short run, without major structural adjustment, could mean the loss of 9 million farming jobs (Wang 2002).

China does not have a comparative advantage in the production of major grains such as wheat, corn and soybeans. A comparison shows that the average prices of these three products in rural markets in the period between 1995 and 2000 were 7 per cent, 30 per cent and 31 per cent higher than their 2000 c.i.f. prices, respectively. It is not surprising, therefore, that imports of soybeans and soybean oil are increasing rapidly. The domestic price of rice is lower than c.i.f. prices, although its average quality is also lower than that of imports. Thus, in the face of increasing imports, domestic production of these grains will decline significantly.

In 2000 and 2001, cereal imports were at moderate levels of 3.15 and 3.44 million tonnes, respectively. Due to surpluses and the low prices of grain in the domestic market, ${ }^{3}$ as a result of the over-supply since 1998, it is unlikely that the TRQ will be fully used in the near future. However, the TRQ is preventing domestic grain prices from recovering to their recent levels. Meanwhile, soybean imports rose to the historically high level of 13.9 million tonnes in 2001, nearly as much as the domestic output (National Bureau of Statistics 2002). This has led to a large surplus in the soybean market. 
It is clear that without major adjustments in the production structure, the growing grain imports will significantly affect farmers' incomes and further widen the rural-urban income gap.

However, the WTO accession provides great possibilities for reforming China's agricultural sector, leading to positive long-run effects on farmers' incomes, as it pushes agriculture towards its comparative advantages and higher efficiencies. In 2002, the area sown to grain in China fell by 2 per cent, whereas the total grain output increased by 1 per cent from the previous year. New breeds of soybean with significantly higher quality and higher oil content were introduced to north-east China, the main region of soybean production (China Central Television News 2003). These are signs indicating that further increases in efficiency in agricultural production are possible in response to the WTO challenge.

However, to increase agricultural efficiency significantly and reduce rural-urban income disparities, not only structural adjustments of agricultural production but also broad changes in China's domestic grain trade policy are needed.

\section{The grain pricing system in China and its inconsistencies with WTO accession}

The current domestic grain trade policy-which provides grain support prices to farmers and almost monopolises the domestic grain trade system-is not only inconsistent with the trade liberalisation but is hardly helpful to farmers.

Agricultural production and domestic trade in agricultural products was partially liberalised in the late 1970 s and early 1980s. These reforms changed the long-term situation of grain supply shortages into surpluses. Grain output increased from 283 million tonnes to 407 million tonnes during the 1978-84 period. Grain production was first stimulated by the rise in state purchasing prices, and subsequently fuelled by the abolition of the people's commune system and introduction of the household responsibility system, which converted the collective-based production system into a private system. Grain production was affected by three prices at that time-the state quota price, the above-quota price, and the market price-but none of them were linked to world market prices. 
In nominal terms, quota prices rose slightly in the 1980s at a time of high inflation. From 1985 to 1990, the real price of the major grains (as a weighted average of the prices of rice, wheat and corn) fell by 22 per cent. Market prices played a role at the margin, whereas government prices had a larger impact on grain production because the volume of state purchases was so large (Wang 2001). As the result of low government prices, grain output remained at the $\mathbf{4 0 0}$ million tonnes level in the middle and late 1980s, while demand for grain increased significantly. The above-quota prices have converged to a level close to market prices since the early 1990s and fluctuated in line with market prices because of less government intervention. This seems to be the main reason for grain production reaching 440 million tonnes in the early and middle 1990s.

Stimulated by the improvement in grain supply, the government decided to liberalise the quota control system in 1993. However, most of the stateowned grain dealers have become partially profit-oriented and expected to make profits from holding grain stocks. This resulted in supply shortages and sudden increases in market prices in the short run, which led farmers to hold their products for expected higher prices. Facing sharp increases in market prices and shortages, the government decided to give up the planned reform and, instead, to increase the quota prices substantially in 1994. Quota prices were further increased in 1995-97 to encourage grain production. In 1997, the level of quota prices in real terms (as a weighted average of the prices of rice, wheat and corn) was 51 per cent higher than in 1993 and 20 per cent higher than in 1985 (Ministry of Agriculture, various years). Domestic prices of several grain products significantly exceeded the world market prices. At the same time, the central government introduced a 'provincial governor responsibility system' to insure local self-sufficiency of grain supplies.

Responding to the higher prices, the area sown to grain increased by 4 per cent and grain yield per hectare increased by 10 per cent between 1994 and 1998. Total grain output reached 504 million tonnes in 1996 and 512 million tonnes in 1998. This output far exceeded domestic demand and resulted in decreases in market prices since 1997.

From 1996 to 2000, market prices of rice, wheat, corn and soybean dropped by 39 per cent, 35 per cent, 44 per cent and 44 per cent, respectively (authors' calculations on the basis of data, Information Centre, Ministry of Agriculture). A model simulation shows that the rigid government 
pricing system has caused serious price and output instability in grain markets (Wang 2001).

The rigidity of the state-monopolised grain trade system and mistakes of the grain trading companies added fuel to the flames of supply surpluses. While domestic supply was increasing, there were net imports of 18.67 and 10.25 million tonnes of grain in 1995 and 1996, respectively, which worsened the situation of domestic grain surpluses.

Faced with the low market prices, the government announced three policies in 1998: all grain products were to be purchased by the state grain companies at support prices that are higher than market prices; the state grain companies would have to sell grain at prices not lower than the support prices, so that the state subsidy could be reduced; and bank loans extended to these companies for the purpose of grain purchases were not to be used for other purposes. In addition, in order to make the support prices work, the grain market was monopolised by the state, and private businesses were prohibited from purchasing grain directly from farmers.

These policies did not achieve the goal of protecting farmers' incomes for several reasons. First, after two decades of market-oriented reform, it was extremely difficult to entirely monopolise grain purchases. Second, the role of policy executers given to the state grain companies conflicted with their role as profit makers. To make profits or to avoid losses, they tended to under-grade the quality of grain they were purchasing from farmers, or make extra deductions for 'wet' and 'impure' grain, so that they could pay no more than market prices. In some cases, they refused to purchase from farmers, only from private dealers, so that under-the-table deals could be made to share the price margin. Third, even if consumer prices could be monopolised at a higher level than would clear the market, the demand for grain was not under state control. As a result, the over-supplied grain could not be sold off and the losses had to be borne by either the state or farmers. In addition, while farmers benefited little from the support prices, the state had to bear the huge cost of storing a large amount of grain and to invest in many new storehouses.

Under these pressures, a few changes were made to partially liberalise the grain markets. First, some low quality grains were excluded from the support list in 2001. Second, up to 2002, the local grain market was 
liberalised in eight east coast provinces that had a grain trade deficit. Third, decision making on support prices was transferred from the central to the provincial governments, resulting in support prices moving closer to market prices.

In spite of these changes, the support price system still conflicted with the market mechanism, and generated more conflict following WTO accession, because it encouraged domestic production of grain which did not have a comparative advantage, and therefore resulted in surpluses and lower market prices. Further liberalisation of the grain market was needed.

\section{Policy considerations in liberalising the grain market}

There are several fears about liberalisation of the grain market.

- Without government protection, farmers may be hurt when the market price of grain is low.

- Without the government purchase and supply of grain, food security may not be assured when there are poor harvests or war threats.

- Liberalisation of the grain market and withdrawal of government subsidies would result in job losses in the state grain trade sector of up to two million.

- The accumulation of huge financial losses and non-performing loans in the state grain sector has been a hot political potato; once the market is liberalised, the non-performing loans in the state sector would need to be liquidated.

Contrary to these opinions, past experience shows that government intervention has resulted in instability of grain supply, larger price fluctuations, inefficient operations, and huge losses in the state grain trade sector. The earlier the state grain trade sector is reformed, the more quickly the losses can be avoided.

In those provinces in which the grain market has been liberalised, the situation is satisfactory, that is price levels, demand and supply are basically stable; the formal state grain companies have been either privatised or restructured; and at least some of these businesses have become profitable. 
Liberalisation of the grain market will have at least some benefits. The grain surplus will soon be absorbed, which will help to stabilise market prices. Market prices formed on the basis of demand and supply will give farmers the best available information on which to base their production decisions. Other agricultural products in which China has comparative advantage, for example, some vegetables, fruits, animal products, and herbal medicines, will replace grains, and this will help to increase farmers' incomes. The accumulated huge losses and non-performing loans in the state grain sector have become a heavy burden on the economy. This burden will be soon removed after liberalisation of the grain market.

However, as well as deregulation, the government needs to be proactive in certain areas.

- Anti-monopoly regulations should be enacted and a market supervision system established to reduce the likelihood of monopolistic practices, whether by government or private traders.

- Due to difficulties in farmers gaining access to market information, the government should accept responsibility for establishing a broad network of information services to provide farmers with supply and demand information and forecasts of the domestic and international food markets.

- In some areas, the agricultural technology support and training systems run by government have played an excellent role in helping farmers to adopt new technology. However, there are still many farmers, particularly in remote areas, who do not enjoy these services. These systems should be expanded. New products, breeds, fertilisers, and other technologies and production methods should be more widely and more quickly introduced and demonstrated to farmers.

- For emergency food supply situations, an effective nation-wide grain reserve system is needed. However, its sole function should be as emergency food supplies. Non-government stocks should not be allowed to perform that role. The current grain reserve system is too large and too complicated and inefficient, run as it is by different government agencies at the central, provincial, and municipal levels. Because of the different interests of the various agencies and the conflicts within and between the agencies, this arrangement can 
hardly serve a national goal. Given a shortage of supply, some agencies may support the market using their reserves, while others may buy and hoard grains to make a profit. Therefore, it is necessary to reform the grain reserve system to give it a single objective and to have it operate under clear guidelines and unified control.

\section{Relationship between rural industrialisation and urbanisation and rural incomes}

Grain market deregulation and structural adjustment in the agricultural sector are important. However, due to the huge surplus of agricultural labour, these measures will not be sufficient to absorb the shock of agricultural internationalisation. Policy adjustments are also needed to accelerate China's rural industrialisation and urbanisation.

During the economic reform period, particularly up to the mid 1990s, rural industry developed very quickly and made a major contribution to China's rapid economic growth (see the World Bank 1996; Cai 2000; and Wang 2000). Employment in the Township and Village Enterprise (TVE) sector increased from 28 million to 135 million during the period 1978-96, accounting for more than one-fourth of the total rural labour force. TVEs produce at least one-quarter of the total industrial output. Development of the TVE sector has also made a great contribution to increases in farmers' incomes. Nearly one-half of rural household income now comes from nonagricultural sources, mainly from the TVE sector. Figure 4.2 shows that the level of rural income per capita in China's 31 provinces is closely associated with provincial achievements in rural industrialisation.

Rural industries experienced substantial development in the 1980s, partially because the rural reform created a better market environment while the urban economy was still heavily subject to central control. Government policies also had an important influence, encouraging development of TVEs in rural areas and discouraging rural-urban migration.

Development of rural industries slowed in the late 1990s, mainly due to sharper market competition, unfavourable location of the rural enterprises, difficulties in external finance, and lack of infrastructure facilities, technical inputs, and human resources. Meanwhile, urbanisation accelerated. Large numbers of rural labourers migrated to urban areas to find jobs. In year 
Figure 4.2 Relationship between rural industrialisation and rural income, 2000

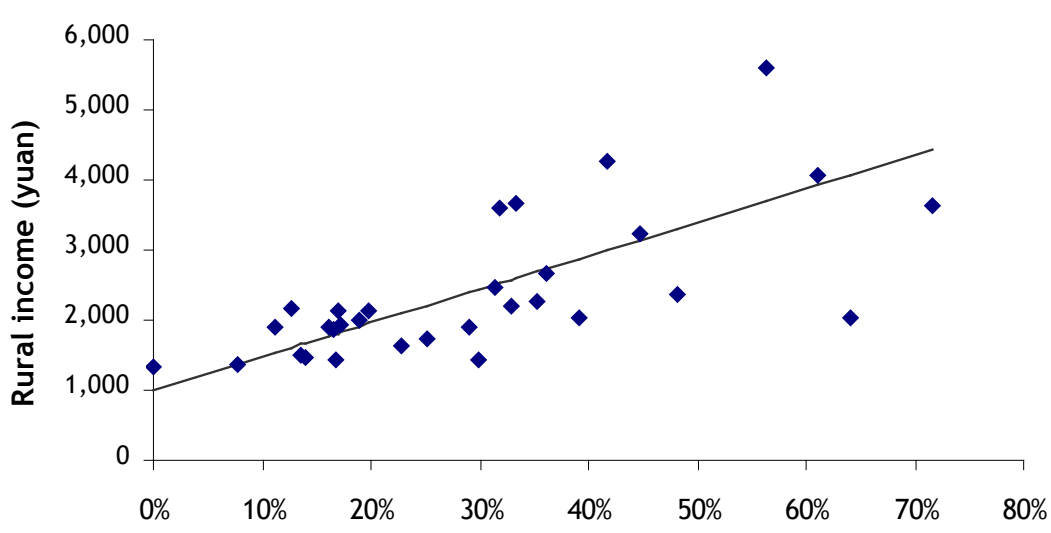

Rural industralisation

Note: Industrialisation is indicated by the share of TVE employment in rural labour. Rural income is per capita rural pure income (yuan).

Source: Calculated from National Bureau of Statistics, 2000a, 2001. Statistical Yearbook of China, China Statistics Press, Beijing.

2001, the urbanisation rate (the ratio of urban to total population) in China reached 38 per cent, whereas it was only 26 per cent in 1990 and 19 per cent in 1980. Improvement in the availability of rural finance will certainly help in the development of rural industries. Nevertheless, the importance of rural industrialisation in the economy is likely to be replaced by urbanisation.

In spite of the acceleration in urban development, the rate of urbanisation in China is still 10-20 percentage points lower than the average of other countries at a similar income level (Wang and Xia 1999). In particular, medium and large cities are in short supply compared with China's large population. In 2000, there were 121 million people living in the cities of 0.5 million population and above, accounting for only 9.6 per cent of the national population. In the less-developed west region, people living in cities of these sizes only account for 5.6 per cent of the region's 
population. If China had a similar urbanisation rate to the average of other countries at a similar income level, there would be an additional 120-240 million people living in urban areas. This number may also be thought of as the excess supply of people in the rural economy.

Figure 4.3 plots the urbanisation rate and rural income of China's 31 provinces in 2000. It indicates a positive relationship between urbanisation

Figure 4.3 Relationship between urbanisation and rural income, 2000

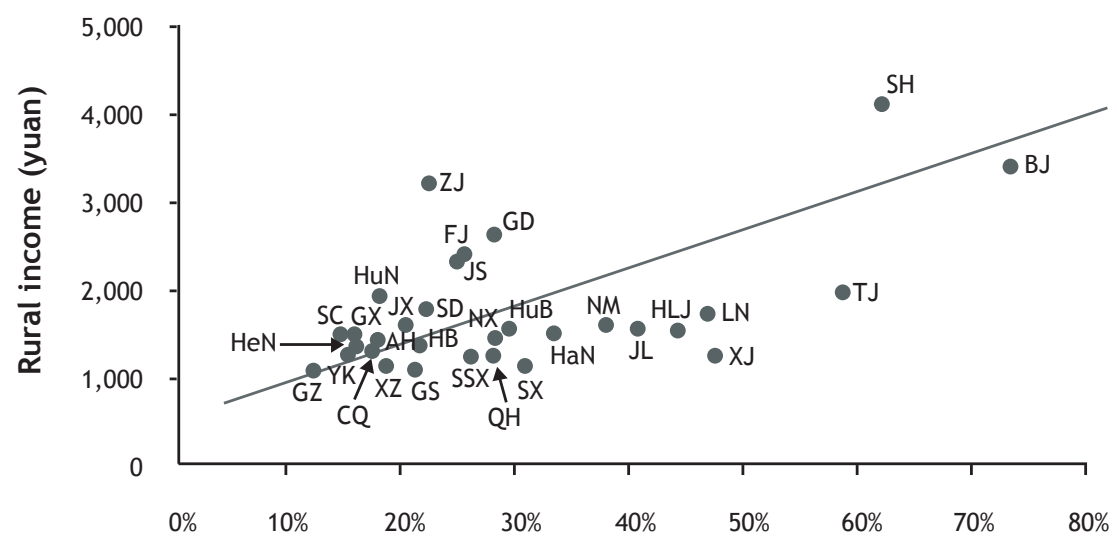

Urbanization rate

Symbols of provinces:

$\begin{array}{lllll}\text { BJ: Beijing } & \text { TJ: Tianjin } & \text { HB: Hebei } & \text { SX: Shanxi } & \text { NM: Neimenggu } \\ \text { LN: Liaoning } & \text { JL: Jilin } & \text { HLJ: Heilongjiang } & \text { SH: Shanghai } & \text { JS: Jiangsu } \\ \text { ZJ: Zhejiang } & \text { AH: Anhui } & \text { FJ: Fujian } & \text { JX: Jiangxi } & \text { SD: Shandong } \\ \text { HeN: Henan } & \text { HuB: Hubei } & \text { HuN: Hunan } & \text { GD: Guangdong } & \text { GX: Guangxi } \\ \text { HaN: Nainan } & \text { CQ: Chongqing } & \text { SC: Sichuan } & \text { GZ: Quizhou } & \text { YN: Yunnan } \\ \text { XZ: Xizang } & \text { SnX: Shannxi } & \text { GS: Gansu } & \text { QH: Qinghai } & \text { NX: Ningxia } \\ \text { XJ: Xinjiang } & & & & \end{array}$

Note: The urbanisation rate used is the proportion of urban to total employment in each province.

Source: National Bureau of Statistics, 2001. Statistical Yearbook of China, China Statistics Press, Beijing. 
and rural income: provinces having a higher urbanisation rate have a higher rural income. This relationship may imply that urbanisation helps to liberate redundant rural labour from arable land and therefore increases agricultural productivity. Considering that one-half of the Chinese labour force is still agricultural labour, urbanisation could have a significant impact on agricultural productivity.

\section{A causality test on the impact of urbanisation and policy considerations}

However, this urbanisation effect does not have to be the only explanation for the relationship shown in Figure 4.3, because both urbanisation and higher rural income can be an outcome of economic growth. In the following, we introduce a growth model to test the causality between urbanisation and regional economic growth. This model has its origins in neoclassical growth models and endogenous growth models (see, for example, Solow 1956; Lucas 1988) but includes variables representing urbanisation:

$$
\mathrm{Y}_{\mathrm{it}}=\mathrm{A}+\mathrm{a}^{1} \mathrm{~K}_{\mathrm{it}}+\mathrm{a}^{2} \mathrm{H}_{\mathrm{it}}+\mathrm{a}^{3} \mathrm{D}_{\mathrm{it}}+\mathrm{a}^{4} \mathrm{~L}+\mathrm{a}^{5} \mathrm{U}_{\mathrm{it}-1}+\mathrm{a}^{6} \mathrm{DU} \mathrm{i}_{\mathrm{i}(\mathrm{t}-1)}+\varepsilon_{\mathrm{it}}
$$

where $\mathrm{Y}_{\mathrm{it}}, \mathrm{K}_{\mathrm{it}}, \mathrm{H}_{\mathrm{it}} \mathrm{D}_{\mathrm{it}}$ and $\mathrm{L}_{\mathrm{it}}$ are growth rates of GDP, capital stock, human resources (indicated by workers' average year of schooling), cultivated land area and total employment, respectively, of the ith province in year $t$. $\mathrm{U}_{\mathrm{it}-1}$ is the urbanisation rate with a one-year lag (the urbanisation rate used is the ratio of urban employment to provincial total employment). $\mathrm{DU}_{\mathrm{i}(\mathrm{t}-1)}$ is the difference of $U_{i}$ between years $t-1$ and $t-2 . \varepsilon$ is the error term.

Lagged variables of $U$ and DU are used for the causality test between urbanisation and economic growth. This specification identifies the effect of urbanisation on growth if $\mathrm{U}$ or DU is significant. The reason for including both $\mathrm{U}$ and DU in the model is to distinguish the possible growth effect (long-run effect) and level effect (short-run effect) of urbanisation. A significant estimate of $U$ indicates a continuing effect of urbanisation on growth (meaning urbanisation brings about higher productivity growth), whereas a significant estimate of DU indicates an impact from changes in the urbanisation rate on growth, which is a short-run effect. 
To impose the restriction of constant returns to scale $\left(a^{3}=1-a^{1}-a^{2}\right)$, both sides of Equation 1 were divided by $\mathrm{L}_{\text {it }}$

$$
\mathrm{y}_{\mathrm{it}}=\mathrm{A}+\mathrm{a}^{1} \mathrm{k}_{\mathrm{it}}+\mathrm{a}^{2} \mathrm{~h}_{\mathrm{it}}+\mathrm{a}^{3} \mathrm{~d}_{\mathrm{it}}+\mathrm{a}^{5} \mathrm{U}_{\mathrm{i}(\mathrm{t}-\mathrm{l})}+\mathrm{a}^{6} \mathrm{DU} \mathrm{U}_{\mathrm{i}(\mathrm{t}-\mathrm{l})}+\varepsilon_{\mathrm{it}}
$$

where $\mathrm{y}, \mathrm{k}, \mathrm{h}$ and $\mathrm{d}$ are $\mathrm{Y}, \mathrm{K}, \mathrm{H}$ and $\mathrm{D}$ divided by $\mathrm{L}$, respectively.

To see the possible differences in the urbanisation effect at the different levels of economic development, $\mathrm{U}_{\mathrm{i}(\mathrm{t}-1)}$ is replaced by three urbanisation variables for the east, central and west regions. The east region is the most developed while the west region is the least developed of the three regions. Similarly, replacements are made to $\mathrm{DU}_{\mathrm{i}(\mathrm{t}-1)}$.

$$
\begin{aligned}
\mathrm{y}_{\mathrm{it}}= & \mathrm{A}+\mathrm{a}^{1} \mathrm{k}_{\mathrm{it}}+\mathrm{a}^{2} \mathrm{~h}_{\mathrm{it}}+\mathrm{a}^{3} \mathrm{~d}_{\mathrm{it}}+\mathrm{a}^{7} \mathrm{U}_{\mathrm{i}(\mathrm{t}-\mathrm{l})}^{1}+\mathrm{a}^{8} \mathrm{U}_{\mathrm{i}(\mathrm{t}-\mathrm{l})}^{2}+\mathrm{a}^{9} \mathrm{U}_{\mathrm{i}(\mathrm{t}-1)}^{3} \\
& +\mathrm{a}^{10} \mathrm{DU} \mathrm{U}_{\mathrm{i}(\mathrm{t}-\mathrm{l})}+\mathrm{a}^{11} \mathrm{DU} \mathrm{U}_{\mathrm{i}(\mathrm{t}-\mathrm{l})}+\mathrm{a}^{12} \mathrm{DU} \mathrm{U}_{\mathrm{i}(\mathrm{t}-\mathrm{l})}+\varepsilon_{\mathrm{it}}
\end{aligned}
$$

Panel data for 25 provinces and covering the 20 years from 1979 to 1998 have been used. The other six provinces were excluded due to incomplete data. Data were provided by Fang Cai and Dewen Wang (2002) and from National Bureau of Statistics (various years and 1999b). Capital stock was calculated from the historical data for capital formation in each province.

Both fixed effects and random effects models were estimated. Hausmann's test rejects the hypothesis of the appropriateness of the random effects model; therefore the results of the fixed effects model are reported in Table 4.3.

The two versions of the model produce similar results. Most coefficients are statistically significant at the 1 per cent level. According to version (1'), the elasticities of capital, human resources, employment and land with respect to economic growth are $0.348,0.431,0.205$ and 0.016 , respectively, all in reasonable ranges. The elasticity of land is minor and insignificant, which is not surprising because the farming sector only contributes a small proportion to the economy. The estimates of $U$ are significant, which indicates that every one percentage point increase in the urbanisation rate accelerates provincial economic growth by 0.37 percentage points over the 7-10 per cent high growth rate. DU is omitted from the model due to 
insignificant coefficient estimates in previous regressions. These results suggest that urbanisation has a long-run impact on economic growth.

The major difference in the results of the second version of the model is the insignificant effect of urbanisation on economic growth in the lessdeveloped west region. The effect is significant in the two other regions. There are two possible reasons for this result: the effect in the west region is insignificant because the achievement of urbanisation in the west has been relatively low or, contrary to the other regions, the urban economy in the west provinces has not experienced much restructuring, and is therefore less market-oriented and less efficient.

In general, the results identify a contribution from urbanisation to economic growth via productivity changes. A reasonable explanation for the higher productivity growth is improvement in resource allocation between the rural and urban sectors. This implies that accelerating urbanisation could be an important measure to counteract the short-run side effects of WTO accession on the agricultural sector, and to reduce the rural-urban income gap.

Table 4.3 Modeling results: urbanisation and economic growth

\begin{tabular}{lcccc} 
& \multicolumn{2}{c}{ Version 1' } & \multicolumn{2}{c}{ Version 2 } \\
Variable & Coefficient & t-ratio & Coefficient & t-ratio \\
K & 0.3481 & $\left(8.891^{* *}\right)$ & 0.3552 & $\left(8.931^{* *}\right)$ \\
H & 0.4315 & $\left(5.122^{* *}\right)$ & 0.4261 & $\left(5.045^{* *}\right)$ \\
D & 0.0157 & $(0.903)$ & 0.0159 & $(0.911)$ \\
Ut-1 & 0.3753 & $\left(3.619^{* *}\right)$ & & \\
U1 & & & 0.3560 & $\left(2.698^{* *}\right)$ \\
U2 & & & 0.5525 & $\left(2.835^{* *}\right)$ \\
U3 & & & 0.0097 & $(0.031)$ \\
Constant & -0.0837 & $\left(-2.383^{*}\right)$ & -0.2119 & $\left(-2.265^{*}\right)$ \\
& Dependent var. & $y$ & Dependent var. & $\mathrm{y}$ \\
& $\mathrm{R}^{2}$ & 0.3697 & $\mathrm{R}^{2}$ & 0.3726
\end{tabular}

Note: $\mathrm{t}$ ratios with * and ${ }^{* *}$ are significant at the 5 per cent and 1 per cent levels, respectively. For simplicity, coefficients of provincial dummy variables are not reported in this table.

Source: Estimation results. Original data from National Bureau of Statistics, 1999b, 2001. Statistical Yearbook of China, China Statistics Press, Beijing. 
Urbanisation in China being behind other countries is mainly a result of the previous central government policies restricting rural-urban migration and growth of large cities. Some of these restrictions have been removed over the past decade, however, rural-urban migration is still partially restricted by the urban household registration system, job entry barriers, non-access or harder access to health care benefits and schooling, and public security protection, for example, against rural migrants. The low level, or lack, of rural education, job training, and employment information services are also barriers against rural-urban migration. Policy adjustments to remove these restrictions, to improve rural education, and to provide government services on job training and employment information services are essential for accelerating urbanisation.

The current urban economy provides limited opportunity for rural migrants because the number and size of cities is limited. Expansion of the urban economy will provide employment opportunities, especially in China's under-developed services sector, which has a significantly higher proportion in the existing urban economy than in the rural economy. It is the government's responsibility to improve urban planning, urban infrastructure, and public utilities in order to promote urban development. With these changes, many small cities and towns can be expected to become large or medium sized cities.

\section{Conclusion}

The agricultural sector in China is seen as being labour-redundant, largely as the result of policies restricting the development of urban areas. These policies are also seen as a major reason for China's large and growing rural-urban income gap. The situation is worsening after the opening of China's grain market resulting from its WTO accession. In particular, the over-regulated domestic grain market and government pricing conflict with the new situation of openness, since these result in over-supply of grains. It is suggested that the domestic grain market should be liberalised and the grain pricing system should be deregulated.

For further solutions to the import shock to the agricultural sector as the result of WTO accession, the roles of rural industrialisation and 
urbanisation are examined. We find that urbanisation has positive effects on rural incomes and regional economic growth. Since the urbanisation rate in China is significantly lower than in other countries at a similar level of GDP per capita, we recommend that urbanisation should be accelerated by deregulating rural-urban migration, promotion of urban infrastructure, improvement in rural education, job training and employment information services.

\section{Notes}

1 Data used in this paper without acknowledgment are from the National Bureau of Statistics.

2 However, this tariff rate is unlikely to be used in normal cases since the quota is large compared with the historical record of grain imports.

3 In real terms, the compound market price of major grains, that is, rice, wheat, corn and soybean, in 2000 was only 57 per cent of the 1995 level and 78 per cent of the 1997 level (calculations by the authors). Ministry of Agriculture Information Centre (various years), Wu 2001 and National Bureau of Statistics (various years).

\section{References}

Cai, Fang, Dewen Wang and Juwei Zhang, 2000. 'Economic growth in China: labour, human capital and employment structure', in Xiaolu Wang and Gang Fan (eds), The Sustainability of China's Economic Growth, Economic Science Press, Beijing.

Cai, Fang and Dewen Wang, 2002. 'Regional comparative advantage in China: differences, changes and its impact on regional disparity', in Xiaolu Wang and Gang Fan (eds), Changing Trend and Influential Factors of Regional Disparity in China, Economic Science Press, Beijing.

China Central Television News, 8 January, 2003.

Ministry of Agriculture, China, Survey data, Information Center, Beijing. Lucas, R.E., 1988. 'On the mechanics of economic development', Journal of Monetary Economics, 22:3-42.

Ministry of Agriculture, China, various years, China Agricultural Development Report, Beijing. 
National Bureau of Statistics, various years and specifically 1999b, 2000a, 2001, 2002. Statistical Yearbook of China, China Statistics Press, Beijing.

Solow, R.M., 1956. 'A contribution to the theory of economic growth', Quarterly Journal of Economics, 70, February, 65-94.

Wang, Xiaolu and Xiaolin Xia, 1999. 'Optimum city size and economic growth', Economic Research, No. 9, Beijing.

Wang, Xiaolu, 2000. 'The role of rural industrialisation in China's economic growth', in Xiaolu Wang and Gang Fan (eds), The Sustainability of China's Economic Growth, Economic Science Press, Beijing.

Wang, Xiaolu, 2001. 'Grain market fluctuations and government intervention in China', research report for the ACIAR project China's Grain Market Policy Reform, The Australian National University, Canberra.

Wang, Xiaolu, 2002. 'The WTO challenge to agriculture', in R. Garnaut and L. Song (eds), China 2002: WTO entry and world recession, Asia Pacific Press, The Australian National University, Canberra:81-96.

World Bank, 1996. The Chinese Economy: Controlling Inflation, Deepening Reform, World Bank, Washington, DC.

World Trade Organization, 2001. Accession of the People's Republic of China, decision of 10 November 2001, World Trade Organization, Geneva.

Wu, Laping, 2001. Price comparison between world and domestic grain markets, prepared for the ACIAR project on China's grain market, The Australian National University, Canberra (unpublished). 